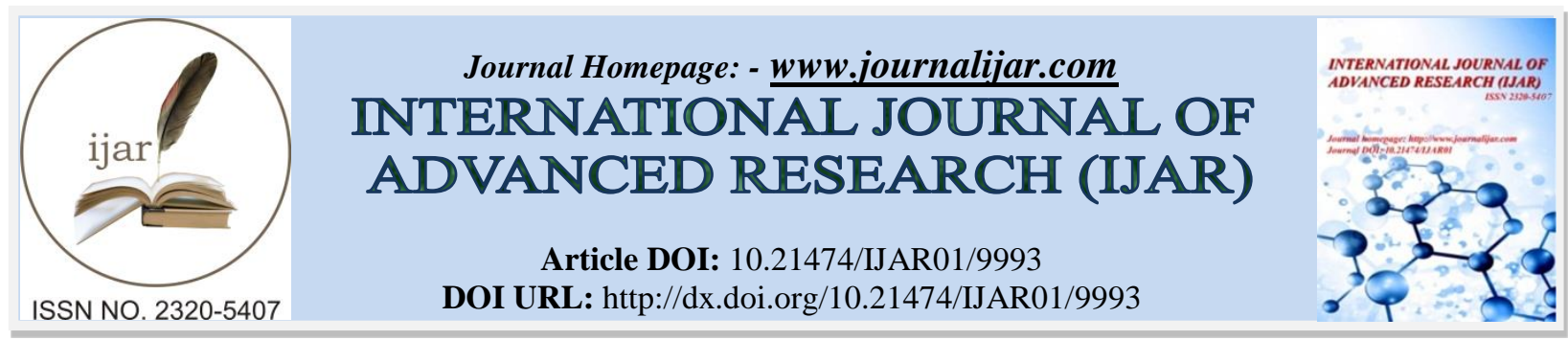

RESEARCH ARTICLE

\title{
INFLUENCE OF TRANSFORMATIONAL LEADERSHIP, ORGANIZATIONAL CULTURE, AND ORGANIZATIONAL COMMITMENT TOWARDS WORK ETHICS OF EMPLOYEE EDUCATION SERVICES IN NORTH BENGKULU REGENCY.
}

\author{
Hendra $^{1}$, Mukhneri ${ }^{2}$ and Ma'ruf ${ }^{2}$. \\ 1. Student, Universitas Negeri Jakarta, Educational Management. \\ 2. Professor, Universitas Negeri Jakarta, Educational Management.
}

\section{Manuscript Info}

\section{Manuscript History}

Received: 05 September 2019

Final Accepted: 07 October 2019

Published: November 2019

Key words:-

Work ethic, Transformational

Leadership, Organizational Culture

Organizational Commitment.

\begin{abstract}
The purpose of this study was to determine the effect of transformational leadership, organizational culture and organizational commitment on the work ethic of North Bengkulu Regency Education Office employees. The study was conducted on a work ethic with a study population of 84 and a sample selection of 69 employees of the North Bengkulu Education Office. This research uses a quantitative approach with a path analysis method. The results showed that: (1) transformational leadership had a direct positive effect on work ethic, (2) organizational culture had a positive direct effect on work ethic, (3) organizational commitment had a positive direct effect on work ethic, (4) transformational leadership had a direct positive effect on organizational commitment, (5) organizational culture has a direct positive effect on organizational commitment, (6) transformational leadership has a direct positive effect on organizational culture. Based on the results of research to improve the work ethic of North Bengkulu district education office employees that need to be improved are Transformational leadership, organizational culture and organizational commitment.
\end{abstract}

Copy Right, IJAR, 2019,. All rights reserved.

\section{Introduction:-}

Civil Servants Act Number 43 of 1999 concerning the performance of Civil Servants states that Civil Servant Development is carried out based on a career and performance system, so that high performance is an embodiment of the quality of Civil Servants and this is quite important in order to support smoothness to achieve the goals organization, (RI, 1999). With high performance, it means that the Civil Servants can truly function as producers of appropriate and effective work in accordance with the goals of the organization they are achieving, a good performance improvement must be accompanied by a good work ethic as well.

The education office is an education center which generally has the task of implementing government affairs, both central and regional in the field of education. The main task is to regulate the implementation of educational affairs according to the work area, so that it runs smoothly and according to programs from the center. To carry out these functions in order to run well, it requires a leader or head of service which is an element of implementing the local government responsible to the Regent in carrying out affairs and targets in the field of education both curriculum,

Corresponding Author:- Hendra.

Address:-Student, Universitas Negeri Jakarta, Educational Management. 
facilities and infrastructure as well as students who can improve the quality of education such as what Gary Yukl said with transformational leadership change, followers gave trust, admiration, loyalty and respect for leaders and they were motivated to do a better job than what they had previously targeted (Yukl, 2010).

In addition to good leaders employees are important assets in an agency, without them how difficult the agency to achieve goals, it is they who determine the progression of an agency, by having skilled workers with culture and high commitment the agency already has very expensive assets, because basically humans are the subject and object of development which is a very important factor, especially improving the quality of human resources is a top priority. Work ethic is an important thing that must be owned by every agency employee, including the North Bengkulu Regional Education Office, because the work ethic is a reflection of the agency's ability to manage and allocate its employees, therefore the work ethic of employees has a very important influence for the ongoing activities agency and influence the process of achieving agency goals.

The mission of the Office of Education is to increase service availability at all levels of education, increase the affordability of services at all levels of education, improve the quality and relevance of services, increase equality in obtaining services, increase the empowerment of science and technology and environmental-friendly IMTAQ.

In fact, in the field, the condition of the education service in North Bengkulu Regency is still inadequate, there are still many internal problems in the education service, as seen from the physical condition of the facilities and infrastructure that are still long and there has been no building renewal since the 90s. In addition, the leakage of employees' work spaces in the rain, and the narrow working space of employees makes the work of employees is not optimal at certain times.

Furthermore, awareness of the responsibilities regarding the spirit of work ethic and motivation is only a small part of the employees who do it. Even according to observations seen employees began to be indifferent to the existing tupoksi tending towards when the new leadership orders to carry out tasks while the existing tupoksi began to be ignored. Besides that, most of the offices and houses of the Education Department employees are quite far away and there are no transportation allowances for employees, employees only rely on transportation money only from the employee's salary. To achieve the above mission with inadequate field conditions, it requires transpormational leadership that builds, culture, climate and good commitment so as to create a good work ethic in carrying out tasks and providing maximum services to the community in the Education Office in the northern Bengkulu district. According to etymologically, the word ethos comes from Greek. Initially the meaning is simple: customs or habits, but this word later evolved and developed to be very rich and complex into "guiding beliefs of a person, group or institution and the characteristic spirit of a culture, era, or community as manifested in its attitudes and aspirations (SInamo, 2013). John P. Meriac defines work ethics as follows, "work ethic is an individual difference construct characterized by a set of beliefs and attitudes reflecting the fundamental value of work (Meriac \& Gorman, 2017). Meriac, J. P., et.al defines the work ethic as follows, "work ethic is defined as" a set of beliefs and attitudes reflecting the fundamental value of work (Meriac \& Gorman, 2017). Transformational leaders involve their followers in their charismatic vision by setting example behavior, challenging their followers' assumptions and ideas and paying attention to their needs. With these behaviors, leaders inspire their followers to shape, alter, and elevate their motives, values, and goals, encourage them to do more than their formal duties and take on extra tasks or responsibilities, update required knowledge and skills, and come up with creative solutions for new problems (Kroon, van Woerkom, \& Menting, 2017). Transformational leadership, the followers of fell trust, admiration, loyalty and respect toward the leader and they are motivated to do more than they originally expected to do. the leader transforms and motivates followers by making them more aware of the importance of task outcomes, inducing them to transcend their own self-interest for the sake of the organization or team and activating their higher order needs (Yukl, 2010). Furthermore Jesse W. Campbell defines transformational leadership as follows, "transformational leadership is closely linked to organizational culture, interpersonal dynamics, and perceived support for innovation (Campbell, 2017). Organizational culture is a very complex topic, in part because culture is so difficult to define. in essence, culture is the set of intangibles that influences attitudes and behavior of $\mathrm{Ni}$ organizations. some of the factors that can influence an organization's culture include the expressed vision of executives, the degree of hierarchy and bureaucracy, the history of interactions among departments, and the style of communication throughout the organization (Heneman III \& Judge, 2015). Edgar H. Schein in his book John R. Schermerhorn said, "organizational culture is the system of shared beliefs and values that shapes and guides the behavior of its members (Schermerhorn, Jr \& Bahrach, 2015). A similar definition is stated by A. William P. Dobson, M. Walter defines, organizational culture consists of the values and assumptions shared within an 
organization. It defines what is important and unimportant in the company and consequently, directs everyone in the organization towards the right way of doing things (McShane \& Von Glinow, 2018).

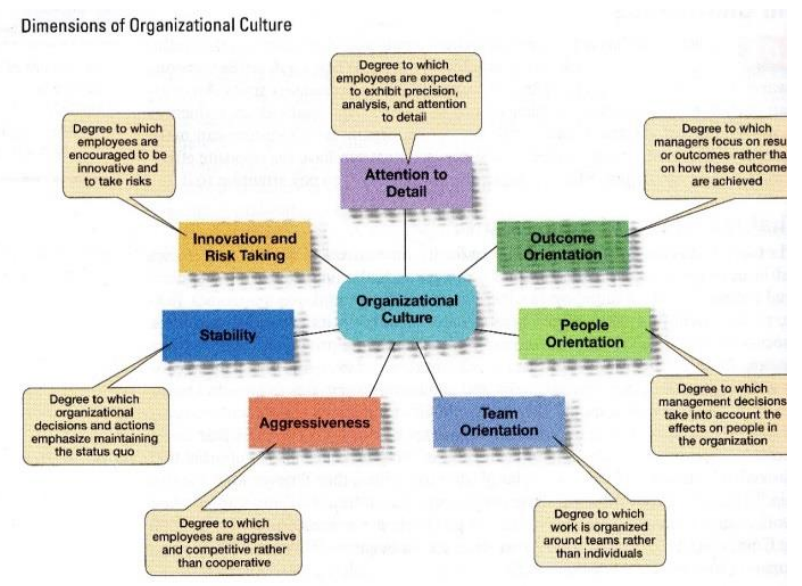

Figure1:-Dimensions of Organizational Culture.

Allen and Meyer define organizational commitment as follows: organizational commitment is commonly defined as a psychological link between the employee and his or her organization that makes it less likely that the employee will voluntarily leave the organization (Farrukh, Ying, \& Mansori, 2017). Timothy T. Baldwin, et.al defines organizational commitment as follows, "organizational commitment is an attitude representing the extent to which an employee identifies with his organization and desires to remain a member of the organization (Baldwin, Bommer, \& Rubin, 2013) . Furthermore Jason A. Colquitt, et.al defines organizational commitment as follows: organizational commitment is defined as the desire on the part of an employee to remain a member of the organization, organizational commitment influences whether an employee stays a member of the organizational (is retained) or leaves to pursue another job (Colquitt et al., 2015). Stephen P. Robbins and Timothy A. Judge define organizational commitment as follows, "organizational commitment is the degree to which an employee identifies with a particular organization and its goals and wishes to maintain membership in the organization (Robbins \& Judge, 2019).

\section{Research Methods:-}

This research uses a quantitative approach, survey methods and path analysis techniques. The variables in the path analysis consist of exogenous and endogenous variables.

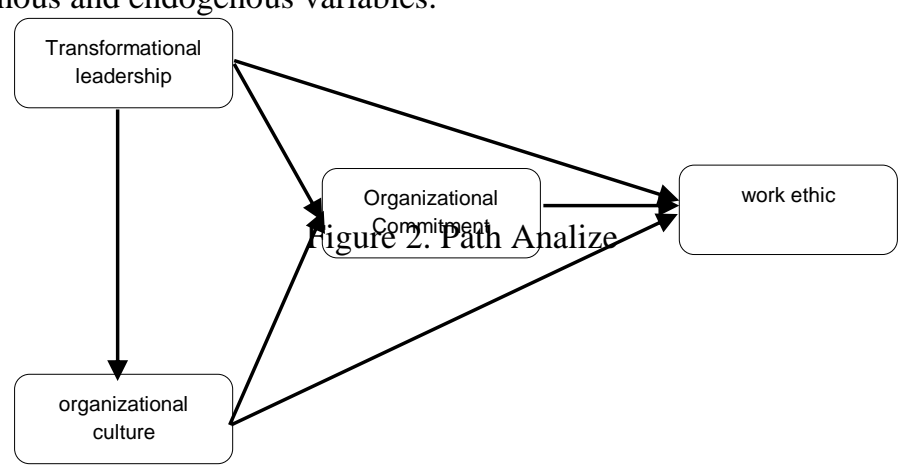

The population in this study were employees of the North Bengkulu Regency Education Office. The sample in this study was a portion of the population. The sampling technique used is random sampling. In this study the collection of data used by using the instrument in the form of a questionnaire. The instrument was tested before being used in research. The testing of the instrument includes a validity test and a reliability test. From the test results obtained items are valid and invalid instruments. Invalid instrument removed. Questionnaires were distributed to respondents to obtain research data on all variables studied. These variables are as follows: Work Ethic, Work Ethic is the attitude of employees in working to support the realization of desired goals in life, with indicators, standards of behavior, mutual trust and moral behavior at work. Instrument Grilles: 
Table 1:-Work Ethic Instrument Grid

\begin{tabular}{|l|l|c|c|}
\hline \multicolumn{1}{|c|}{ Indicator } & \multicolumn{1}{|c|}{ item number } & Drop & Total \\
\hline 1. Standards of behavior & $1,2,3,4,5,6,7,8,9,10$ & 10 & 9 \\
2. Mutual trust & $11,12,13,14,15,16,17,18,19,20$ & & 10 \\
3. Moral behavior at work & $21,22,23,24,25,26,27,28,29,30$ & & \\
\hline \multicolumn{1}{|c|}{ Total } & 24 & 14 \\
\hline
\end{tabular}

Transformational leadership is the behavior of employee leaders who are able to work together with other employees to optimally empower organizational resources in order to achieve meaningful goals in accordance with the targets set by the indicators: inspire, create stimulus, build organizations and visionary, instrument lattice as follows:

Table 2:-Lines of Transformational Leadership Instruments

\begin{tabular}{|l|l|c|c|}
\hline \multicolumn{1}{|c|}{ Indicator } & \multicolumn{1}{|c|}{ Item Number } & Drop & Jumlah \\
\hline 1. Inspiration & $1,2,3,4,5,6,7,8$ & 7 & 7 \\
2. Make a stimulus & $9,10,11,12,13,14,15,16$ & & 8 \\
3. Building Organization & $17,18,19,20,21,22,23,24$ & 17,20 & 6 \\
4. Visioner & $25,26,27,28,29,30,31,32$ & 33 & 10 \\
& $33,34,35$ & & \\
\hline \multicolumn{2}{|l|}{ Jumlah } & & $\mathbf{3 1}$ \\
\hline
\end{tabular}

Organizational culture is the values and norms that are mutually agreed upon and adhered to by members in an organization to be used as a guide to do their work to support the achievement of their organizational goals with indicators: norms, applicable regulations, symbols, and values, the instrument lines are as follows:

Table 3:-Organizational Cultural Instrument Grid

\begin{tabular}{|l|l|c|c|}
\hline \multicolumn{1}{|c|}{ Indicator } & \multicolumn{1}{c|}{ Item Number } & Drop & Total \\
\hline 1. & Norms & $1,2,3,4,5,6,7,8,9,10$ & 10 \\
2. Applicable Regulation & $11,12,13,14,15,16,17,18$ & 11,18 & 6 \\
3. Symbols & $19,20,21,22,23,24,25,26$ & 8 \\
$4 . \quad$ Value & $27,28,29,30,31,32,33,34,35$ & 32 & 8 \\
\hline \multicolumn{2}{|c|}{ Total } & & \\
\hline
\end{tabular}

Organizational commitment is the partisanship of employees as permanent members of the organization to the organization by taking an active and responsible role in order to achieve its objectives, with indicators, being loyal to the organization, identifying with the organization, ownership of the organization, and participating. The instrument grilles are as follows:

Table 4:-Organizational Commitment Instrument Grid

\begin{tabular}{|c|c|c|c|}
\hline Indikator & Item number & Drop & Total \\
\hline $\begin{array}{ll}\text { 1. } & \text { Be loyal to } \\
\text { 2. } & \text { Sense of belonging to organization } \\
\text { 3. } & \text { Participate }\end{array}$ & $\begin{array}{l}1,2,3,4,5,6,7,8,9,10 \\
11,12,13,14,15,16,17,18 \\
19,20,21,22,23 \\
24,25,26,27,28,29,30 \\
31,32,33,34,35\end{array}$ & $\begin{array}{l}12 \\
33\end{array}$ & $\begin{array}{l}10 \\
12 \\
11\end{array}$ \\
\hline \multicolumn{2}{|c|}{ Total } & & 32 \\
\hline
\end{tabular}

\section{Research Results and Discussion:-}

Work Ethic (Y) From the data obtained in the field which are then processed statistically into a frequency distribution list, the number of classes is calculated according to Sturges rules, seven classes are obtained with a maximum score of 147 and a minimum score of 122, so the range of scores is 25 . The results of the calculation of the data are obtained on average in the amount of 135.20; standard deviation of 6.09; variance of 37.0759; a median of 135; and mode of 134. Grouping work ethic data can be seen in the frequency distribution table as follows. 
Table 5:-Frequency Distribution of Work Ethics

\begin{tabular}{|c|c|c|c|c|c|c|c|c|}
\hline \multirow{2}{*}{ No } & \multicolumn{2}{l}{ Interval Class } & \multicolumn{2}{c|}{ Limit } & \multicolumn{3}{c|}{ Frequency } \\
\cline { 5 - 9 } & \multicolumn{2}{|l|}{} & Down & Up & Absolute & Relatif & Komulatif \\
\hline 1 & 122 & - & 125 & 121,5 & 125,5 & 4 & $5,80 \%$ & $5,80 \%$ \\
\hline 2 & 126 & - & 129 & 125,5 & 129,5 & 10 & $14,49 \%$ & $20,29 \%$ \\
\hline 3 & 130 & - & 133 & 129,5 & 133,5 & 12 & $17,39 \%$ & $37,68 \%$ \\
\hline 4 & 134 & - & 137 & 133,5 & 137,5 & 18 & $26,09 \%$ & $63,77 \%$ \\
\hline 5 & 138 & - & 141 & 137,5 & 141,5 & 12 & $17,39 \%$ & $81,16 \%$ \\
\hline 6 & 142 & - & 145 & 141,5 & 145,5 & 10 & $14,49 \%$ & $95,65 \%$ \\
\hline 7 & 146 & - & 149 & 145,5 & 149,5 & 3 & $4,35 \%$ & $100 \%$ \\
\hline & & & & & & $\mathbf{6 9}$ & $\mathbf{1 0 0 \%}$ & \\
\hline
\end{tabular}

Transformational leadership (X1) data has an empirical score range of 115 to 135 , so that the range of scores is 20 . The results of data calculations obtained an average of 125.55; standard deviation of 5.09; variance of 25.9275; a median of 125; and mode of 125. Grouping of transformational leadership data can be seen in the frequency distribution table as follows.

Table 6:-Frequency Distribution of Transformational Leadership

\begin{tabular}{|c|c|c|c|c|c|c|c|c|}
\hline \multirow{2}{*}{ No } & \multicolumn{2}{|l|}{ Interval Class } & \multicolumn{2}{|c|}{ Limit } & \multicolumn{3}{c|}{ Frequency } \\
\cline { 5 - 8 } & \multicolumn{2}{|l|}{} & Down & Up & Absolute & Relatif & Komulatif \\
\hline 1 & 115 & - & 117 & 114,5 & 117,5 & 5 & $7,25 \%$ & $7,25 \%$ \\
\hline 2 & 118 & - & 120 & 117,5 & 120,5 & 7 & $10,14 \%$ & $17,39 \%$ \\
\hline 3 & 121 & - & 123 & 120,5 & 123,5 & 12 & $17,39 \%$ & $34,78 \%$ \\
\hline 4 & 124 & - & 126 & 123,5 & 126,5 & 16 & $23,19 \%$ & $57,97 \%$ \\
\hline 5 & 127 & - & 129 & 126,5 & 129,5 & 12 & $17,39 \%$ & $75,36 \%$ \\
\hline 6 & 130 & - & 132 & 129,5 & 132,5 & 10 & $14,49 \%$ & $89,86 \%$ \\
\hline 7 & 133 & - & 135 & 132,5 & 135,5 & 7 & $10,14 \%$ & $100 \%$ \\
\hline & & & & & & $\mathbf{6 9}$ & $\mathbf{1 0 0 \%}$ & \\
\hline
\end{tabular}

Organizational culture (X2) data has an empirical score range of 114 to 139 , so the range of scores is 25 . The results of data calculations obtained an average of 127.67; standard deviation of 6.07; variance of 36.8726; a median of 127; and mode of 127. Grouping organizational culture data can be seen in the frequency distribution table as follows.

Table 7:-Distribution of Organizational Culture Frequencies

\begin{tabular}{|c|c|c|c|c|c|c|c|c|}
\hline \multirow{2}{*}{ No } & \multicolumn{2}{|l|}{ Interval Class } & \multicolumn{2}{c|}{ Limit } & \multicolumn{2}{c|}{ Frequency } \\
\cline { 5 - 9 } & \multicolumn{2}{|l|}{} & Down & Up & Absolute & \multicolumn{2}{c|}{ Relatif } & Komulatif \\
\hline 1 & 114 & - & 117 & 113,5 & 117,5 & 3 & $4,35 \%$ & $4,35 \%$ \\
\hline 2 & 118 & - & 121 & 117,5 & 121,5 & 9 & $13,04 \%$ & $17,39 \%$ \\
\hline 3 & 122 & - & 125 & 121,5 & 125,5 & 13 & $18,84 \%$ & $36,23 \%$ \\
\hline 4 & 126 & - & 129 & 125,5 & 129,5 & 17 & $24,64 \%$ & $60,87 \%$ \\
\hline 5 & 130 & - & 133 & 129,5 & 133,5 & 13 & $18,84 \%$ & $79,71 \%$ \\
\hline 6 & 134 & - & 137 & 133,5 & 137,5 & 11 & $15,94 \%$ & $95,65 \%$ \\
\hline 7 & 138 & - & 141 & 137,5 & 141,5 & 3 & $4,35 \%$ & $100 \%$ \\
\hline & & & & & & $\mathbf{6 9}$ & $\mathbf{1 0 0 \%}$ & \\
\hline
\end{tabular}

Organizational commitment (X3) data has an empirical score range of 122 to 147 , so that the range of scores is 25 . The results of data calculations obtained an average of 136.81; standard deviation of 5.53; variance of 30.6257; a median of 136; and mode of 136. Grouping data on organizational commitment can be seen in the frequency distribution table as follows.

Taebl 8:-Frequency Distribution of Organizational Commitments

\begin{tabular}{|c|c|c|c|c|c|c|c|c|}
\hline \multirow{2}{*}{ No } & \multicolumn{2}{|l|}{ Interval Class } & \multicolumn{2}{c|}{ Limit } & \multicolumn{2}{c|}{ Frequency } \\
\cline { 4 - 8 } & \multicolumn{2}{|l|}{} & Down & Up & Absolute & Relatif & Komulatif \\
\hline 1 & 122 & - & 125 & 121,5 & 125,5 & 2 & $2,90 \%$ & $2,90 \%$ \\
\hline
\end{tabular}




\begin{tabular}{|c|c|c|c|c|c|c|c|c|}
\hline 2 & 126 & - & 129 & 125,5 & 129,5 & 5 & $7,25 \%$ & $10,14 \%$ \\
\hline 3 & 130 & - & 133 & 129,5 & 133,5 & 13 & $18,84 \%$ & $28,99 \%$ \\
\hline 4 & 134 & - & 137 & 133,5 & 137,5 & 20 & $28,99 \%$ & $57,97 \%$ \\
\hline 5 & 138 & - & 141 & 137,5 & 141,5 & 14 & $20,29 \%$ & $78,26 \%$ \\
\hline 6 & 142 & - & 145 & 141,5 & 145,5 & 10 & $14,49 \%$ & $92,75 \%$ \\
\hline 7 & 146 & - & 149 & 145,5 & 149,5 & 5 & $7,25 \%$ & $100 \%$ \\
\hline & & & & & & $\mathbf{6 9}$ & $\mathbf{1 0 0 \%}$ & \\
\hline
\end{tabular}

Normality Test, The data used in compiling the regression model must meet the assumption that the data comes from normally distributed populations. The normality assumption basically states that in a regression model it must be normally distributed. The assumption test in this study was carried out by testing the normality of data from the six error estimation of the research regression to be analyzed. The normality test uses the SPSS program to find out whether the Y Over X regression is normal or not, the results of which can be seen in the Kolmogorov Smirnov column (Sig.).

Table 9:-Test Results for Regression Estimation Normality

\begin{tabular}{|l|r|r|r|r|r|r|}
\hline & \multicolumn{3}{|c|}{ Kolmogorov-Smirnov(a) } & \multicolumn{3}{|c|}{ Shapiro-Wilk } \\
\cline { 2 - 7 } & Statistic & df & \multicolumn{1}{c|}{ Sig. } & Statistic & df & \multicolumn{1}{c|}{ Sig. } \\
\hline Y up X1 &, 056 & 69 &, $200\left(^{*}\right)$ &, 983 & 69 &, 447 \\
\hline Y up X2 &, 066 & 69 &, $200\left(^{*}\right)$ &, 986 & 69 &, 638 \\
\hline Y up X3 &, 087 & 69 &, $200\left(^{*}\right)$ &, 976 & 69 &, 195 \\
\hline X3 up X1 &, 083 & 69 &, $200\left(^{*}\right)$ &, 961 & 69 &, 031 \\
\hline X3 up X2 &, 060 & 69 &, $200\left(^{*}\right)$ &, 988 & 69 &, 758 \\
\hline X2 up X1 &, 066 & 69 &, $200\left(^{*}\right)$ &, 984 & 69 &, 535 \\
\hline
\end{tabular}

Table 10:-Test Results for Regression Estimation Normality

\begin{tabular}{|l|r|r|r|r|r|r|}
\hline & \multicolumn{4}{|c|}{ Kolmogorov-Smirnov(a) } & \multicolumn{3}{c|}{ Shapiro-Wilk } \\
\cline { 2 - 8 } & Statistic & df & \multicolumn{1}{c|}{ Sig. } & Statistic & df & \multicolumn{1}{c|}{ Sig. } \\
\hline Y up X1 &, 056 & 69 &, $200\left(^{*}\right)$ &, 983 & 69 &, 447 \\
\hline Y up X2 &, 066 & 69 &, $200\left(^{*}\right)$ &, 986 & 69 &, 638 \\
\hline Y up X3 &, 087 & 69 &, $200\left(^{*}\right)$ &, 976 & 69 &, 195 \\
\hline X3 up X1 &, 083 & 69 &, $200\left(^{*}\right)$ &, 961 & 69 &, 031 \\
\hline X3 up X2 &, 060 & 69 &, $200\left(^{*}\right)$ &, 988 & 69 &, 758 \\
\hline X2 up X1 &, 066 & 69 &, $200\left(^{*}\right)$ &, 984 & 69 &, 535 \\
\hline
\end{tabular}

The table above shows that the probability value (Sig.) Of all regression estimation errors is 0.200 . The probability value is greater than the significant level $(\alpha) 0.05$, so all of the estimated error data are normally distributed regression.

Table 11:-Test the Significance of Work Ethic Regression on Transformational Leadership

\begin{tabular}{|l|l|r|r|r|r|r|}
\hline Model & & \multicolumn{1}{c|}{$\begin{array}{c}\text { Sum of } \\
\text { Squares }\end{array}$} & \multicolumn{1}{c|}{ Mf } & Mean Square & F & \multicolumn{1}{c|}{ Sig. } \\
\hline 1 & Regression & 970,818 & 1 & 970,818 & 41,955 &, $000(\mathrm{a})$ \\
\hline & Residual & 1550,341 & 67 & 23,139 & & \\
\hline & Total & 2521,159 & 68 & & & \\
\hline
\end{tabular}

Table 12:-Regression Linearity Tests of Organizational Commitment to Organizational Culture

\begin{tabular}{|c|c|c|c|c|c|c|c|}
\hline & & & $\begin{array}{l}\text { Sum of } \\
\text { Squares }\end{array}$ & df & $\begin{array}{l}\text { Mean } \\
\text { Square }\end{array}$ & $\mathrm{F}$ & Sig. \\
\hline \multirow{4}{*}{$\begin{array}{l}\text { Organizational } \\
\text { Comitment (X3) * } \\
\text { Organzational } \\
\text { Culture (X2) }\end{array}$} & \multirow{3}{*}{$\begin{array}{l}\text { Between } \\
\text { Groups }\end{array}$} & (Combined) & 933,334 & 23 & 40,580 & 1,589 & ,091 \\
\hline & & Linearity & 396,176 & 1 & 396,176 & 15,513 & 000 \\
\hline & & $\begin{array}{l}\text { Deviation } \\
\text { from Linearity }\end{array}$ & 537,158 & 22 & 24,416 & ,956 & ,531 \\
\hline & \multicolumn{2}{|c|}{ Within Groups } & 1149,217 & 45 & 25,538 & & \\
\hline
\end{tabular}




\section{Total}

2082,551

68

Table distribution of $\mathrm{F}$ using the free degrees $(\mathrm{db})$ numerator $=22$ and the denominator $\mathrm{db}=45$ with a significant level of 0.05 . Obtained Ftable of 1.78 and Fcount of 0.956 . This shows that Fcount <F table and probability value Sig. deviation from linearity $(0.531)>$ significant level $(0.05)$ then the estimated point distribution forming a linear line can be accepted. Visually regression X3 over X2.

Table 13:-Test the Significance of Organizational Cultural Regression on Transformational Leadership

\begin{tabular}{|l|l|r|r|r|r|r|}
\hline Model & & $\begin{array}{c}\text { Sum of } \\
\text { Squares }\end{array}$ & \multicolumn{1}{c|}{ df } & Mean Square & F & Sig. \\
\hline 1 & Regression & 254,359 & 1 & 254,359 & 7,564 &, $008(\mathrm{a})$ \\
\hline & Residual & 2252,974 & 67 & 33,626 & & \\
\hline & Total & 2507,333 & 68 & & & \\
\hline
\end{tabular}

Table distribution of $\mathrm{F}$ using the free degrees $(\mathrm{db})$ numerator $=1$ and the denominator $\mathrm{db}(\mathrm{n}-2)=67$ with $\mathrm{a}$ significant level of 0.05 . Obtained Ftabel of 3.98 and Fcount of 7.564. This shows that Fcount> F table and probability value Sig. (0.008) <significant level (0.05), the regression equation X2 over X1 is declared very significant.

\section{Positive Direct Effect of Transformational Leadership (X1) on the Work Ethic (Y)}

Path coefficient py1 greater than 0.05 can be interpreted that the correlation value of r1y which is 0.621 occurs because of the indirect effects of other variables. The effect / direct influence of transformational leadership (X1) on work ethic (Y) is 0.351 while indirectly through organizational culture (X2) is 0.110 through organizational commitment (X3) is 0.122 so the total effect of transformational leadership (X1) on work ethic (Y) amounted to 0.583 .

In addition transformational leadership can generate extra effort from North Bengkulu Regency Education Office employees in working, increasing productivity, increasing work ethic and higher job satisfaction. The influence of the transformational head of the Education Office is the improvement in the performance of North Bengkulu Regency Education Office employees. The head of the transformational education office has a greater impact if it occurs from the bottom up and can be more complex (Robbins \& Judge, 2019). The Head of the Transformational Education Office can also depend on the work of North Bengkulu District Education Office employees such as the transformational Head of the Education Office can empower Bengkulu District Education Office employees to develop ideas, increase capacity, increase self-confidence besides that the transformational Head of Education Office staff can improve the work ethic of Bengkulu Regency Education Office employee. This can help the Head of the Education Office focus on the group or increase subordinates' trust in the leadership.

\section{Positive Direct Effect of Organizational Culture (X2) on Work Ethics (Y)}

Path coefficient py2 greater than 0.05 can be interpreted that the correlation value of r2y of magnitude 0.614 occurs because of the indirect effects of other variables. The effect / direct influence of organizational culture (X2) on work ethic (Y) is 0.345 while indirectly through organizational commitment (X3) is 0.119 so that the total influence of organizational culture (X2) on work ethic (Y) is 0.464 .

Mcshane said: organizational culture consists of values and assumptions shared within an organization. It defines what is important and unimportant in the company and consequently, directs all employees in the organization towards the right way of doing things (McShane \& Von Glinow, 2018). Organizational culture consists of values, shared assumptions in an organization. Define what is important and not important in the agency and consequently direct all employees in the agency towards the right way of doing things.

\section{Positive Direct Effect of Organizational Commitment (X3) on the Work Ethic (Y)}

The results of the third hypothesis analysis produce findings that organizational commitment has a direct positive effect on work ethic. Based on these findings it can be concluded that the work ethic is directly affected positively by organizational commitment. Increased organizational commitment will result in an increase in work ethic. The results of this study are in line with the opinions of several experts including Susan J. Linz and Yu-Wei Luke Chu explained that organizational commitment can strongly influence the work ethic of an employee, the following is further explanation: Individuals who have a work ethic are those who have high values in doing a good job; those who are committed to work a positive relationship between work ethic and performance are explained partly by the 
quality and quantity of work effort spent on work and partly by fewer days not at work. (Linz \& Luke Chu, 2013) Questions are logical, but unanswered in the scientific and social management literature, is whether individuals who exhibit stronger work ethics get more.

\section{Positive Direct Effect of Transformational Leadership (X1) on Organizational Commitment (X3)}

The results of the fourth hypothesis analysis provide findings that transformational leadership has a direct positive effect on organizational commitment. Based on these findings it can be concluded that organizational commitment is directly affected positively by transformational leadership. Increased transformational leadership will result in increased organizational commitment. The results of this study are in line with the opinions of several experts including Steven L. McShane and Mary Von Glionow, saying there are several descriptions of transformational leadership but include four elements. These elements include creating a strategic vision, communicating the vision, modeling the vision and building a commitment to the vision (McShane \& Von Glinow, 2018). Transforming the vision into reality requires the commitment of North Bengkulu Regency Education Office staff. The head of the transformational Education Office built this commitment in several ways.

Furthermore Laurie J. Mullins said: transformational leadership is the process of generating motivation and commitment, creating a vision to transform organizational performance and appealing to the ideals and values of higher followers (Mullins, 2016). A transformational head of the Education Office can give birth to the motivation and commitment of his subordinates or Bengkulu District Education Office employees in creating a vision to change the organization's performance better and the attention of North Bengkulu Regency Education Office employees to hang their ideals higher for mutual progress.

\section{Positive Direct Effect of Organizational Culture (X2) on Organizational Commitment (X3)}

The results of the fifth hypothesis analysis produce findings that organizational culture has a direct positive effect on organizational commitment. Based on these findings it can be concluded that organizational commitment is directly affected positively by organizational culture. Increasing organizational culture will result in increased organizational commitment. The results of this study are in line with the opinions of several experts, including Victor Miroshnik, saying that the commitment comes from the organizational culture in which the North Bengkulu Regency Education Department employees work. This is caused that commitment can be formed from the culture of the organization around them. Commitment is a social action that refers to the binding of employees to certain values in the pursuit of organizational goals. indeed, according to Porter and colleagues, the core of commitment is the relative strength of the identification of individuals with and involvement in certain organizations. thus commitment is formed under the strong influence of values which are a component of organizational culture (Miroshnik, 2013)

\section{Positive Direct Effect of transformational leadership (X1) on Organizational Culture (X2)}

The results of the sixth hypothesis analysis provide findings that transformational leadership has a direct positive effect on organizational culture. Based on these findings it can be concluded that organizational culture is directly affected positively by transformational leadership. Increased transformational leadership will lead to an increase in organizational culture.

Laurie J. Mullins reinforces the views of Achua and Lussier: the right approach can increase organizational effectiveness by increasing the quality of work life through more challenging and satisfying work coupled with the involvement and commitment of employees and their representatives (Mullins, 2016). The most appropriate approach in increasing employee work involvement through increasing organizational commitment is that in addition to improving work ethic it can have an impact on improving the quality of work life of employees. Mullins further stated: transformational leadership is the process of generating motivation and commitment, creating a vision to transform organizational performance and appealing to the ideals and values of higher followers (Mullins, 2016). Implementation of transformational leader style can give birth to employee motivation in work and organizational commitment of employees to their work, besides that through the process of inspiring the right and visionary leader views can improve employee work ethic.

Indirect Effects of Organizational Culture (X2) on Work Ethics (Y) through Organizational Commitment (X3) The results of the eighth hypothesis provide findings that there is an indirect influence of organizational culture on work ethic through organizational commitment. So as to improve the work ethic of employees, it can be done by increasing organizational culture so that organizational commitment increases. This means that organizational culture is important to improve employee work ethics. 
Furthermore Victoria Miroshnik said that commitment comes from the organizational culture where employees work. This is caused that commitment can be formed from the culture of the organization around them. Commitment is a social action that refers to one's binding of certain values in the pursuit of organizational goals. indeed, according to Porter and colleagues, the core of commitment is the relative strength of the identification of individuals with and involvement in certain organizations. thus commitment is formed under the strong influence of values which are a component of organizational culture (Miroshnik, 2013).

\section{Conclusion:-}

Based on the analysis of transformational leadership variables, organizational culture, organizational commitment and work ethic can be concluded as follows;

1. Transformational leadership has a direct positive effect on work ethic. This means that when leaders in the Bengkulu District Education Office implement transformations, they can improve employee work ethics

2. Organizational culture has a direct positive effect on work ethic. This means that good organizational culture and maximum performance can help improve work ethic.

3. Organizational commitment has a direct positive effect on work ethic. This means that employee commitment to the organization reflects the employee work ethic

4. Transformational leadership has a direct positive effect on organizational commitment. This means that transformational leadership is needed in the formation of a sense of commitment in North Bengkulu Education Office employees.

5. Organizational culture has a direct positive effect on organizational commitment. This means that a well-run organizational culture can increase employee organizational commitment to the institution

6. Transformational leadership has a direct positive effect on organizational culture. This means that in the formation of a good organizational culture transformational leadership is needed.

\section{Refrences:-}

1. Achua, C. F., \& Lussier, R. N. (2010). Effective Leadership (4th ed.). Canada: South-Western Cengage Learning.

2. Baldwin, T. T., Bommer, W. H., \& Rubin, R. S. (2013). Managing Organizational Behaviour What Great Manager Know \& Do (2nd ed.). United State of America: McGraw-Hill Irwin.

3. Campbell, J. W. (2017). Red tape and transformational leadership: an organizational echelons perspective. Journal of Organizational Change Management, 30(1), 76-90. https://doi.org/10.1108/JOCM-01-2016-0004

4. Cassidy, C. M., \& Kreitner, R. (2011). Principles of management (12th ed.). England: Cengage Learning.

5. Cheng, T. . E., Podoisky, S., \& Jarvis, P. (1996). Just-in Time Manufactruing an Introduction. London: Spiner.

6. Colquitt, J., LePine, J. A., \& Wesson, M. J. (2015). Organizational behavior: improving performance and commitment in the workplace (Fourth edition). New York, NY: McGraw-Hill Education.

7. Daft, R. L. (2015). The Leadership experience (Sixth edition). Stamford, CT, USA: Cengage Learning.

8. Danim, S. (2007). Visi Baru Manajemen Sekolah dari Unit Birokrasi ke Lembaga Akademik. Jakarta: PT Bumi Aksara.

9. Farrukh, M., Ying, C. W., \& Mansori, S. (2017). Organizational commitment: an empirical analysis of personality traits. Journal of Work-Applied Management, 9(1), 18-34. https://doi.org/10.1108/JWAM-12-20160026

10. Forquesato, P. (2016). Social norms of work ethic and incentives in organizations. Journal of Economic Behavior and Organization, 128, 231-250. https://doi.org/10.1016/j.jebo.2016.05.012

11. Gibson, J. L., Ivancevich, J. M., Donnelly, Jr, J. H., \& Konopaske, R. (2012). Organizations: Behavior, Structure, Processes.

12. Greenberg, J. (2011). Behavior in Organizations (10th ed.). England: Pearson Education.

13. Griffin, R. W., \& Moorhead, G. (2014). Organizational behavior: managing people and organizations (11th Edition). Australia: South-Western/Cengage Learning.

14. Heacock, I. (2010). Defining The Work Ethic. Inida: Departemen of Sociology Indiana University Bloomington.

15. Hellriegel, D., \& Slocum, J. W. (2011). Organizational behavior (13th ed). Mason, Ohio: South-Western Cengage Learning.

16. Heneman III, H. G., \& Judge, T. A. (2015). Staffing Organizations (8th ed.). Singapore: McGraw-Hill Education. 
17. Hill, C. W. L., \& Jones, G. R. (2009). Essentials of strategic management (2nd ed). Australia ; Mason, Ohio: South-Western/Cengage Learning.

18. Jones, G. R., \& George, J. M. (2016). Contemporary management (Ninth edition). New York, NY: McGrawHill Education.

19. Kreitner, R., \& Kinicki, A. (2010). Organizational Behavior (9th ed.). New York: McGraw-Hill Irwin.

20. Kroon, B., van Woerkom, M., \& Menting, C. (2017). Mindfulness as substitute for transformational leadership. Journal of Managerial Psychology, 32(4), 284-297. https://doi.org/10.1108/JMP-07-2016-0223

21. Linz, S. J., \& Luke Chu, Y.-W. (2013). Work ethic in formerly socialist economies. Journal of Economic Psychology, 39, 185-203. https://doi.org/10.1016/j.joep.2013.07.010

22. Luthans, F. (2012). Organizational behavior an evidence-based approach 12th edition.

23. Luthans, F., \& Doh, J. P. (2018). International management: culture, strategy, and behavior (Tenth Edition). Dubuque: McGraw-Hill Education.

24. Manetje, O., \& Martins, N. (2009). The relationship between organisational culture and organisational commitment, 25.

25. Manning, G., \& Curtis, K. (2015). The Art of Leadership 5 Edition. New York: Mc Graw-Hill.

26. McShane, S. L., \& Von Glinow, M. A. Y. (2018). Organizational behavior: emerging knowledge, global reality (Eighth edition). New York, NY: McGraw-Hill Education.

27. Meriac, J. P., \& Gorman, C. A. (2017). Work Ethic and Work Outcomes in an Expanded Criterion Domain. Journal of Business and Psychology, 32(3), 273-282. https://doi.org/10.1007/s10869-016-9460-y

28. Miller, G. (2002). The Frontier, Entrepreneurialism, and Engineers: Women Coping with a Web of Masculinities in an Organizational Culture. Culture and Organization, 8(2), 145-160. https://doi.org/10.1080/14759550212836

29. Miroshnik, V. (2013). Organizational Culture and Commitment Transmission in Multinationals. New York: Palgrave Macmillan.

30. Mullins, L. J. (2016). Management \& organisational behaviour (Eleventh Edition). Harlow, England; New York: Pearson.

31. Nelson, D. L., \& Campbell Quick, J. (2011). Organizational Behavior Science, the Real World and You (7th ed.). United State: South-Western Cengage Learning.

32. Newstroom, J. W. (2014). Organizational Behavior Human Behavior At Work (14th ed.). New York: Mc GrawHill.

33. Porter, K., Smith, P., Fagg, R., \& Winfield, P. W. (2006). Leadership and management for HR professionals. Amsterdam; Oxford: Butterworth-Heinemann.

34. Poza, E. J. (2010). Family business (3rd ed). Mason, Ohio: South-Western Cengage Learning.

35. Robbins, S. P., \& Coulter, M. K. (2016). Management (13th edition). Boston: Pearson.

36. Robbins, S. P., \& Judge, T. A. (2019). Organizational Behavior (18th ed.). England: Pearson Education Limited.

37. Schermerhorn, J. R., Osborn, R. N., Uhl-Bien, M., \& Hunt, J. G. (2012). Organizational Behavior (12th ed.). Asia: John Wiley \& Sons, Ltd.

38. Schermerhorn, Jr, J. R., \& Bahrach, D. G. (2015). Introduction to Management (13th ed.). Asia: Wiley.

39. Scott, S. G., \& Bruce, R. A. (1994). DETERMINANTS OF INNOVATIVE BEHAVIOR: A PATH MODEL OF INDIVIDUAL INNOVATION IN THE WORKPLACE. Academy of Management Journal, 37(3), 580607. https://doi.org/10.2307/256701

40. SInamo, J. (2013). 8 Professional Work Ethic. Jakarta: Institut Darma Mahardika.

41. Trigunarsyah, B. (2017). Organizational culture influence on client involvement. Engineering, Construction and Architectural Management, 24(6), 1155-1169. https://doi.org/10.1108/ECAM-06-2016-0141

42. Vecchio, R. (2006). Organizational Behavior : Core Concepts (6th ed.). Ohio: Thompson Coorporation.

43. What are Work Ethics. (2002). Retrieved January 29, 2019, from https://www.allaboutphilosophy.org/what-arework-ethics-faq.htm

44. Why Work Ethic. (2010, June 29). Retrieved January 29, 2019, from https://news.uga.edu/why-work-ethic

45. Wibowo, W. (2014). Behavior in Organizations.. Jakarta: PT RajaGrafindo.

46. Wirawan, W. (2008). Cultural and organizational climate Theory, Application and Research. Jakarta: Salemba Empat.

47. Yukl, G. A. (2010). Leadership in organizations (7th ed). Upper Saddle River, N.J: Prentice Hall. 